\title{
ON BEING ASKED FOR A WAR POEM: W. B. YEATS AND THE ROLE OF THE POET DURING WORLD WAR I
}

\author{
Marina Naves ${ }^{1}$ \\ Valéria Pereira ${ }^{2}$
}

\begin{abstract}
Resumo: Partindo da análise de dois poemas escritos por W. B. Yeats, On being asked for a war poem e An Irish airman foresees his death, discute-se, sob a perspectiva do nacionalismo anticolonial irlandês, o papel do poeta durante a Grande Guerra. Em Yeats, tal ofício não é criar um ideário militar glorioso (ou, ainda, expressar os traumas do soldado britânico que defende sua terra), mas manter-se calado - como no primeiro poema - ou, ainda, de expor a estupidez, insolência e frivolidade que o conflito para ele representava. Pelo autor apreende-se, também, a expressão da triste e peculiar contradição que é morrer por uma nação que não se ama — pior, que mantém dominada a sua própria pátria —, como aparece no segundo poema. Desse modo, destrinchando as duas obras é possível, também, reler a Primeira Guerra Mundial por meio de um olhar que não se volta para manutenção de disputas e políticas imperialistas; pelo contrário, que as contrapõe e as questiona.
\end{abstract}

Palavras-chave: William Butler Yeats; Primeira Guerra Mundial; nacionalismo irlandês.

Abstract: Analyzing two poems written by W. B. Yeats, On being asked for a war poem and An Irish airman foresees his death, the role of the poet during the Great War can be discussed under the perspective of the Irish anti colonial nationalism. In Yeats' poetry, the art of writing has no purpose of creating a military ideal of glory (or even to express the traumas of the British soldiers defending their homeland), but to keep silent — as in the first poem — , or even to expose the frivolity and stupidity represented by the conflict. One also sees in the poems the expression of a sad and peculiar contradiction: that of dying for a country that you do not love - worse, that is the ruler of your own nation, as appears in the second poem. Through the analysis of the two texts it is possible, therefore, to reimagine the Great War, through a perspective of those who are not concerned with maintaining imperialistic rule, but destroying it. Keywords: William Butler Yeats; World War I; Irish nationalism.

\footnotetext{
1 Graduanda em Letras na UFMG, Bolsista de Iniciação Científica do CNPq.

2 Professora na Faculdade de Letras da Universidade Federal de Minas Gerais e coordenadora pedagógica de língua alemã na UFMG.
} 


\section{WILLIAM BUTLER YEATS: A NATIONAL POET}

Born in County Dublin, Ireland, in 1865, Yeats, Nobel prize winner for literature of 1923, is considered one of the most important modernist poets and playwrights of the English language. As a young man, his poetry was Romantic and mystical, influenced by Shelley and the Pre-Raphaelite Brotherhood. His collection of essays, The Celtic Twilight, is a good example of how this style was adopted by the writer in his youth, but this style soon came under the influence of the modernist Ezra Pound.

Perhaps because of his inclination towards Celtic culture, Yeats became a close friend of Lady Gregory, an aristocrat who shared his interest in the Irish lore. Together, they were of great importance for the Irish Literary Revival (a "renaissance" period of the late 19th to early 20th centuries, deeply influenced by a growing regard for the Gaelic language and heritage), as well as the construction of the Abbey Theatre. According to Javier Padilla, W. H. Auden would consider Yeats "as a modernist poet who fits well within both his own poetic genealogy and socially engaged cultural project" (PADILLA, 2018, p. 109), reflecting the poet's project of creating a literary oeuvre that would endorse national unity in Ireland.

Speaking of national matters, it is important to discuss Yeatsian nationalism. Much different from the socialists of the Irish Citizen Army, the poet believed in a traditional lifestyle, which lead Edward Said to say that "his fantasies of old homes and families, his incoherently occult divagations" is "a particularly exacerbated example of nativist (e.g. négritude) phenomenon" (SAID, 1990, p. 81). His nationalist ideals, which were encouraged by Lady Gregory, were responsible for his position as favorable toward the Irish rebels that sought independence from the British Empire. He would even write several famous poems on the topic, thus becoming the national bard of the Easter Rising.

As the poet of the rebels and singing of those who fought to achieve freedom from the British, would mean his opposition to World War I as a way to oppose British imperialism. Specifically, his verse drama Cathleen ní Houlihan would play an important role, since it tells the tale of an old woman, Ireland herself, who seduced young men to fight for her as part of the construction of the rebel ideology of heroic sacrifice for the country's liberty: "to the republican insurrectionist P. S. O'Hegarty, the drama became at once a sacred sacrament; to the rebel Countess Markievicz a kind of gospel" (KIBERD, 1995, p. 200).

It is therefore possible to say that Yeats did not support war if it were only in the British interest, since he would be in favor of an armed conflict initiated by the Irish uprising. Yet, before going into the relation between Yeats and the Great War, let us first understand two backgrounds for such writings: the conflicts in Ireland (and their origins) and the Great War itself.

\section{IRISH CONFLICTS}

Traced back to the English complete colonization of the island in 1536, Ireland has been a place of great conflicts for independence. The subordination to the London-based government, the religious conflict caused by the arrival of protestant settlers and the cons- 
tant discrimination of the English against the Irish catholics have made peace impossible between the colony and the metropole. Many were the civil wars and tensions along the centuries, so let us focus on the events that are closer to the 20th century.

First of all, the Irish Rebellion of 1798: influenced by the American and French revolutions, a group of rebels named The United Irishmen decided to gather forces against Great Britain. Doomed to fail, they were suppressed by the British and over ten thousand people died. This rebellion is important because it was one of the first ones to have a republican alignment, the same of those that contemporary to Yeats. Moreover, this uprising was portrayed in the previously cited play, Cathleen ni Houlihan. The war to which the old woman, Ireland herself, seduces men to go to is precisely the Rebellion of 1798 , an expression of the importance of such rising to the Irish nationalist memory.

The Great Famine is also an important factor that contributed to the nationalist wave which lead to the conflicts that Yeats experienced. In the period of 1845 to 1849, circa a million people died and of starvation and diseases and a million more emigrated, mostly to the United States. The cause to such a disaster was a potato blight that infected the plantations throughout the country and also throughout Europe. Most of the Irishmen that died were those that spoke the Irish Gaelic, causing the culture and the language to almost disappear (being only revived by nationalists such as Patrick Pearse, that thought the mother tongue of Ireland in the St. Enda school). The neglection of the British government to the Irish population during the Great Famine endorsed the bad relation between Ireland and Great Britain, increasing even more the republican ideals among natives and those that emigrated. A good example of Irish-american nationalist was Éamon de Valera, one of the leaders of the Easter Rising which was not executed because he was born in America.

When talking about the conflicts in Ireland, it is also important to mention the Home Rule movement. It was a claim for self-government that intended to end the subordination to the London parliament, but did not mean being independent from Great Britain. It was a way of achieving certain freedom through political and parliamentary means, which would oppose to the Fenian movement (the strange name comes from Na Fianna Éreann, the soldiers of Ireland, a group of heroes of the Irish mythology) that sought to win independence through violence and terrorists acts. The Home Rule League and the Irish Parliamentary Party would together attempt some Home Rule Bills — which failed. This movement divided the country into those that wanted to keep British rule (Ulster, on the North) and those that did not.

After the failed attempts to achieve freedom through the Home Rule Bills, a shift occurred on the minds of the nationalists, who started to prefer the Fenian methods rather than the peaceful parliamentary means of action. Such a shift would lead, then, to the construction of the Easter Rising of 1916, which happened after the gathering of several distinct forces - the Irish Volunteers, the Irish Citizen Army (ICA), and the all-female group Cumann na mBan - on the Easter week. The Rising was very unpopular at first, but the way the rebels were executed, as "the British saw their action as treachery" and "shot its leaders as casually as they shot daily deserters on the western front" (KIBERD, 1995, p. 199) changed the whole view of the people on the event. 
Here is where Yeats appears with his writing of many poems on the event. The poet plays the important role of glorifying, in his own way, the Irish rebels. Yeats' poems on the Easter Rising tends to come back to the idea of kleos (glory) of the ancient Greeks (VIEIRA, 2013), since he eternalize in his verses the deeds of those who sacrificed themselves (for some of them knew the rebellion was doomed to fail and still went fighting on the streets of Dublin) for the liberation of their country from British rule. The poem The Rose Tree is a very interesting way to express how this sacrifice was important, as in its form of conversation between two leaders of the Rising, Connolly and Patrick Pearse, it metaphors blood as the water necessary to save the rose tree from drought:

O plain as plain can be

There's nothing but our own red blood

Can make a right Rose Tree.

(YEATS, 1950, p. 206)

Indeed, there is a deep notion of martyrdom in these verses. Since many of the rebels were catholics of strong belief, the notion of sacrificing themselves on the Easter holiday (the one in which Jesus made his own sacrifice) adopted a very religious connotation. The rebels were considered "Catholic militants, because of the use of Easter symbolism" (KIBERD, 1995, p. 207) who "took Irish asceticism out of the monasteries and made it active in the political world" (KIBERD, 1995, p. 210). Hence, it can be noticed that they were considered political martyrs (because of their sacrifice for the country), but also religious ones since - they believed they were fighting not only for the nation, but for the Catholic faith.

Easter, 1916 is also an interesting poem that follows a very similar idea to the previous one. It does not glorify the rebels as much as the other, but it brings the idea of "terrible beauty" to the cause, giving the armed conflict an heroic aura without taking its horrors out of scene. Evoking the green color - the color of Ireland, the Emerald Isle - the verses pictures the importance of the leaders to the whole concept of modern Ireland, giving them glory - not of the blind kind, but critical; since they created beauty, but a terrible one. It is indeed a very important motto when analyzing war literature on the 20th century.

One of the reasons that made the Rising possible was the Great War, once it distracted Great Britain. Having this in mind, it is necessary to also better understand the conflict, its literature, its relation with Ireland and how this specific background influenced the nationalist cause and also the ideals of Yeats himself, which was against World War I (since it was a war of the British to fight, not the Irish), but not against the war in Ireland.

\section{THE GREAT WAR}

When reading the literature produced during the Great War, it is common to come 
across with different, contrasting images and opinions regarding the event. Some works glorify soldiers and nations, acting "on the imagination of the young to shape a sense of national purpose and inspire a bellicose spirit” (BROSMAN, 1992, p.86); others, on the contrary, denounce the horror and slaughter of the trenches.

To have a good example of glorifying writing of war, one would easily go back to Homer's Iliad. Warriors, such as Achilles, went to war not only to conquer or pillage, but also to achieve glory (kléos), idea previously mentioned. Dying on the battlefield was an heroic honor, since your deeds for the victory of your people would be part of the songs of the bards (aoidos).

The nationalist idea of dying for one's nation — and not only for glory — would also join this glorious view on war. Sure, there was also those that, during the Great War, wrote poetry with nationalists purposes and in order to glorify the event. A good example is Rupert Brooke's The Soldier, in which the poet expresses the sorrow of a soldier who dies in battlefield, but that still feels certain happiness since his country is safe and glorious. Besides all changes that the trenches and the horrors of the Great War had on literature and culture, still some of the poets celebrated dying for king and country, as in Horace's "dulce et decorum est pro patria mori".

However, in modern days the demistifying writing of the war became greater and stronger, most due to the new technologies that would change the western world and its perspectives on armed conflicts. Siegfried Sassoon and Wilfred Owen are good examples of writers that endorsed the growing ideal of a rupture with the glorious narrative of war and the adoption of a more critical view on such events. Owen, expressed in his poetry the terrors of the gas and the trenches. In his poems dwells a sorrow for the lives of young men that died in battlefield for the good of the "old Lie" and the pursuit of glory: the pride of dying for one's country; indeed, he visits Horace's phrase cited, giving it a new, modern significance.

Gas! GAS! Quick, boys!_An ecstasy of fumbling

Fitting the clumsy helmets just in time,

But someone still was yelling out and stumbling

And flound'ring like a man in fire or lime.

(...)

My friend, you would not tell with such high zest

To children ardent for some desperate glory, 
The old Lie: Dulce et decorum est

Pro patria mori.

(OWEN, 1963, p. 55)

Still, before discussing Yeats, it is important to consider the background in which he wrote his "Great War poems". The first one to be discussed, On being asked for a war poem, was written in 1915, one year after the beginning of the event which transformed the warfare of armed conflicts. The poem is indeed a skeptical vision on this new, imperialist type of war that introduced great advances in belic technology, with weapons of greater mortal power than the others ever made. The second one, An Irish airman foresees his death, leads to the memory of the Somme, one of the most emblematic battles of World War I. The Somme offensive was projected in a way that forced the Germans to redirect the soldiers and efforts to the region of Verdun, where the chances of losing the war were greater. The German historians remember the Somme as the offensive that defined the outcome of the war; in the other hand, the battle is remembered by Great Britain for the shame its first day was. Excessively confident on their capacities - and knowing very little of the German side - the British sent their men to die. Just in the first day, more than 19.000 men died, only on the British side of the offensive - among them, several Irishmen. It was he largest battle of the Western Front, which had it's trenches as the sepulchre of about a million men; hence, it was one of the bloodiest battles of human history. Although it defined the war, the Somme battle continues being remembered for having been the moment in which the soldiers and citizens became aware of the limitations of Great Britain and that the event had costed many lives.

\section{THE POEMS}

While "the war to end war" was taking place in Europe, the Irish citizens were occupied with their very own war, the Easter Rising. In fact, it is possible to say that Yeats had to choose between the two wars, since they were both incompatible. Now, despite his decision of not writing about World War I, Yeats still wrote a couple of poems about the event, not being "as absolutely detached as he liked to pretend" (FOSTER, 2000). The first one, On being asked for a war poem (1915), was written in response to a letter of Edith Wharton, who asked him to donate a poem to The Book of the Homeless, a compilation of poems, essays, etc., that intended to fund civilians who were displaced by the war:

I think it better that in times like these

A poet's mouth be silent, for in truth 
We have no gift to set a statesman right;

He has had enough of meddling who can please

A young girl in the indolence of her youth,

Or an old man upon a winter's night.

(YEATS, 1950, p. 175)

In Yeats own words (in a letter to Henry James, Wharton's intermediary), the poem would be "the only thing I have written of the war or will write, so I hope it may not seem unfitting. I shall keep the neighbourhood of the seven sleepers of Ephesus, hoping to catch their comfortable snores till bloody frivolity is over" (YEATS, 1954, p. 599-600). These words well express the intentions of the poem itself, which cherish the idea that the poets should remain silent and aside from the matters of the war.

It may seem, by the poem, the Yeats was contrary to the idea that literature should write about social and political matters, since he comes back to the image of the poet as the one who simply pleases young girls and old, melancholy men at the end of their lives (winter's night), which recovers the romantic view of poetry and literature. Yet, it is rather a poetic strategy than an apathetic view of his own time. This position taken by the Yeats in the poem is a way of maintaining his nationalist position; that is, keeping himself neutral to the war that was, for the Irishmen like him, a "bloody frivolity" - a colonial war of the English and the Europeans that had nothing to do with Ireland. Besides, the poem exposes certain impatience at the effort of writing about the event at all, since "in truth, we [poets] have no gift to set a statesman right".

One event in particular, however, would change Yeats non-commitment to the Great War: the death of Major Robert Gregory, a young artist who was not only an Irish airman who served the Royal Flying Corps, fighting for Britain in Italy, but also the son of Lady Gregory - a close friend of the poet previously cited. Ironically, his death is believed to be by friendly fire - which leads once more to the idea of fighting for the wrong army.

At the request of Lady Gregory, Yeats wrote several elegies for Robert, but in a specific one, An Irish airman foresees his death (1918), he finally writes his war poem, although not as The Book of the Homeless would have wanted. The poet does not endorse the glory of dying for "king and country". On the contrary, in the first four verses of the poem already endeavours to reverse the heroic idea of dying for the success and supremacy of one's country, since the nation for which the lyrical subject dies is not the one he loves, and the enemies he faces are not his own - worse, he fights for those who his own people are trying to be free of.

I know that I shall meet my fate

Somewhere among the clouds above; 
Those that I fight I do not hate,

Those that I guard I do not love

(YEATS, 1950, p. 152)

The following four verses continue the idea of displacement and lack of purpose in the airman's hour of dying: his country is not England, nor the English are his people. On the contrary, his beloved home was Kiltartan Cross, a barony of County Galway where Lady Gregory lived. The use of "poor" leads to the idea that Ireland was a very poor country at the time, having one of the worst slums in Europe.

My country is Kiltartan Cross,

My countrymen Kiltartan's poor,

No likely end could bring them loss

Or leave them happier than before.

(YEATS, 1950, p. 152)

These verses also expose a reality in the lives of Irish young men: "in 1918, even moderate nationalist opinion had turned against the war effort, and farmer's sons were determined to stay home and bring in the harvest rather than be conscripted for slaughter in Europe" (FOSTER, 2000). Finally, the rest of the poem brings a sense of lack of sympathy for the cause for which the airman was fighting - that is, the imperialist cause. Staying in Ireland, however, does not sound, by the verses, a very exciting option as well, which seems that the subject feels equally apathetic for both worlds.

Nor law, nor duty bade me fight,

Nor public men, nor cheering crowds,

A lonely impulse of delight

Drove to this tumult in the clouds;

I balanced all, brought all to mind,

The years to come seemed waste of breath,

A waste of breath the years behind 
In balance with this life, this death.

(YEATS, 1950, p. 152)

This change in Yeats attitude towards the Great War is also a change in the Irish culture of "not talking about the war" - recently, World War I has become an important part of Irish history: the experiences of ex-soldiers and the importance of the war, which has weakened Britain, to the whole planning of the Easter Rising, for instance. Throughout these years of 1914-1918, Yeats, who began certain of his role during the war, ended up following a very self-conscious path, writing and expressing his opinions on the events that were not only taking place around him, but "changing utterly" (to quote his own poem Easter, 1916) Ireland and Europe.

Thus, it is possible to say that both poems assume different positions on the Great War, but although different, they have the same motivation. In the first one, the poet decides to keep silent about the matters of the World War, since he believes it is not a fight for the Irish to worry about, but their colonizers (specially having in mind that the conflict in Europe was a consequence of imperialist measures - and Ireland was far from being part of imperialism). However, the second poem calls the attention to the problem of the deaths of Irishmen that were fighting for Britain, exposing that the poet no longer could remain silent, but had to express the horrors of dying for the glory of the country which is not yours. In this way, a growing maturity can be noticed in the poets ways of taking (or not) position on the event that, even not being primarily of Irish concern, had great effects on the Irish lives that could not be ignored.

\section{CONCLUSION}

Thus, it can be seen that Yeats plays a very peculiar part when it comes to the writing of poetry during World War I. The element of nationalism create a whole knew position towards the war; he does not express the horrors of the trenches nor does he glorify the dead soldiers as he did to the rebels of the Easter Rising, for instance. The poem Sixteen dead men expresses this particular form of war poetry of his:

You say that we should still the land

Till Germany's overcome;

But who is there to argue that

Now Pearse is deaf and dumb?

(YEATS, 1950, p. 205) 
Alluding to the English conflict against Germany, as well as the Irish duty as part of British Empire of defending the land against the foreign enemy, the poet inverts the logic of such obligation by citing Pearse, one of the rebel leaders who were shot after the Irish uprising. This inversion of his create certain sense of worthlessness in fighting against the Germans while it also creates a strong eager of taking Pearse's place and following his steps for the freedom of Ireland. Indeed, the poem switches the importance of the great event happening in Europe to the small, particular one that was happening on the Emerald Isle.

Therefore, it is possible to say that Yeats was not against all armed conflicts: his position is specifically against World War I, since he believed the reasons of such a war was not important for an Irishmen. He does not stop believing that the conflict in Europe was a frivolity he even writes about the Great War after its end in his poem Second Coming, describing it as "mere anarchy" and as a "blood-dimmed tide" (YEATS, 1965, p. 210-211), foreseeing World War II in the following verse "surely the Second Coming is at hand" (YEATS, 1965, p. 210-211) even with all the sorrow he had to face over the death of many Irish soldiers.

Hence, unlike poets such as Sassoon, Owen and Brooke, whose main topic was the Great War per se - which lead the to discuss the issues of the trenches and the honour of dying defending the glory of the British Empire. Yeats' role was to use World War I to emphasize the sacrifice of the Irishmen that were fighting for their homeland - but not against Germany, the great foe, but the "dominion of an offshore power" (SAID, 1990, p. 69). 


\section{WORKS CITED}

BROSMAN, Catherine Savage. The Functions of War Literature. South Central Review, [S. 1.], 1992

FOSTER, R. F. Yeats at war: poetic strategies and political reconstruction from the Easter Rising to the Free State. Transactions of the Royal Historical Society, [S.1.], v. 11, p. 125-145, jul. 2000.

KIBERD, Declan. Inventing Ireland. London: Jonathan Cape, 1995.

OWEN, Wilfred. The collected poems of Wilfred Owen. London: Chatto \& Windus, 1963.

PADILLA, Javier. Yeats's Meditative Spaces: Between Modernity and Coloniality. Journal of Modern Literature, Indiana, v. 41, n. 4, p. 107-124, 2018.

PEREIRA, Valéria S. "Narrar através de imagens: A representação da Batalha do Somme por Joe Sacco.” In: Literatura e Autoritarismo, Dossiê 17, 2016, p.53-61.

SAID, Edward W. Yeats and decolonization. In: EAGLETON, Terry; JAMESON, Frederic; SAID, Edward W. Nationalism, colonialism and literature. Minneapolis: University of Minnesota Press, 1990.

VIEIRA, Luiz Gustavo Leitão. A escrita da guerra: areté, nóstos e kléos na análise de narrativas de guerra. 2013. Tese (Doutorado) - Universidade Federal de Minas Gerais, Belo Horizonte, 2013.

YEATS, W. B. The collected poems of W. B. Yeats. London: Macmillan \& CO LTD, 1950.

YEATS, W. B; WADE, Allan. The letters of W. B. Yeats. London: Rupert Hart-Davis, 1954. 
